\section{Rapid Method for Separation of Microsatellite Alleles by the PhastSystem}

\section{Zsuzsa Buzás ${ }^{1}$ and László Varga}

${ }^{1}$ Institute for Biochemistry and Protein Research, ${ }^{2}$ Institute for Molecular Genetics, Agricultural Biotechnology Center, H-2101, Gödöllö, Hungary
Microsatellites are tandemly repeated short (1-6 bp) simple sequences that are highly abundant in most eukaryotic genomes. ${ }^{(1-4)}$ Because of the variation in the number of repeats, these microsatellites show extensive length polymorphism. Thus, they are very effective as genetic markers for linkage analysis, paternity testing, or population analysis.

Microsatellites are detected by using PCR, and the resulting products are separated by agarose or polyacrylamide gel electrophoresis. ${ }^{(5)}$ As alleles often differ in length by only $2 \mathrm{bp}$, the most accurate detection can be achieved by radioactive PCR and denaturing sequencing gels.

In this paper we report an alternative nonisotopic, high-resolution method for the separation of microsatellite alleles on a partially automated electrophoretic system, the PhastSystem (Pharmacia).

\section{MATERIALS AND METHODS}

Amplification of a murine microsatellite D4Mit $27^{(6)}$ was carried out in $10-\mu l$ volume containing $50 \mathrm{ng}$ of genomic DNA, $120 \mathrm{nM}$ of each primer, $2 \mathrm{mM} \mathrm{MgCl}_{2}, 200$ $\mu \mathrm{M}$ of each dNTP, and 0.5 units of Taq polymerase (Promega). A first denaturation step at $94^{\circ} \mathrm{C}$ for $3 \mathrm{~min}$ was followed by 32 cycles of $1 \mathrm{~min}$ denaturation at $94^{\circ} \mathrm{C}, 1 \mathrm{~min}$ annealing at $55^{\circ} \mathrm{C}$, and 1 min primer extension at $72^{\circ} \mathrm{C}$ and a final extension for $3 \mathrm{~min}$ at $72^{\circ} \mathrm{C}$.

For separation of alleles we used a discontinuous buffer system originally introduced for the separation of SDS proteins, ${ }^{(7)}$ modified in its stacking limits to make it applicable for gel electrophoresis of nucleic acids. ${ }^{(8)}$ This electrophoretic system markedly improves the resolution of bands by taking advantage of the different electrochemical properties of buffers and allowing for the determination of relative mobility $\left(R_{\mathrm{f}}\right)$ values for fragment identification; $R_{\mathrm{f}}$ values are expressed as the ratio of the migration distance of any fragment to that of the moving boundary.

The homemade nondenaturing polyacrylamide gels $(50 \times 43 \times 0.5 \mathrm{~mm})$ were cast on GelBond PAG film (FMC) using the Pharmacia gel cassette. The length of the stacking gel $\left(5 \% \mathrm{~T} 3 \% \mathrm{C}_{\mathrm{Bis}} ; 0.4 \mathrm{M}\right.$ Bistris, $0.1 \mathrm{M} \mathrm{H}_{2} \mathrm{SO}_{4}, 2.2 \mathrm{mM}$ AMPS, $8.6 \mathrm{~mm}$ TEMED at $\mathrm{pH}$ 6.7) was $15 \mathrm{~mm}$, whereas the resolving gel $\left(8 \% \mathrm{~T} 5 \% \mathrm{C}_{\text {Bis }} ; 0.4 \mathrm{M}\right.$ Tris, $0.045 \mathrm{M} \mathrm{H}_{2} \mathrm{SO}_{4}, 1.75 \mathrm{~mm}$ AMPS, 6 mM TEMED at $\mathrm{pH} 8.6$ ) was $35 \mathrm{~mm}$ long. Gel buffer strips were made from $2.8 \%$ agarose IsoGel (FMC). The agarose was melted in the appropriate buffer (cathode buffer, $0.2 \mathrm{~m}$ bicine, $0.1 \mathrm{M} \mathrm{NaOH}$ at pH 8.2; anode buffer, $0.2 \mathrm{M}$ Tris, $0.05 \mathrm{M}$ $\mathrm{H}_{2} \mathrm{SO}_{4}$ at $\mathrm{pH}$ 8.1) and then poured in the molds. The gels were run with constant current $(10 \mathrm{~mA})$ at $15^{\circ} \mathrm{C}$ for $45 \mathrm{Vh}(\sim 20$ $\mathrm{min})$ and silver stained ( $\sim 40 \mathrm{~min})$.

\section{RESULTS AND DISCUSSION}

Two D4Mit27 microsatellite genotypes with three alleles were separated on a $6 \%$ denaturing polyacrylamide sequencing gel (Fig. 1). The same DNA samples were separated on an $8 \%$ nondenaturing polyacrylamide gel by the PhastSystem (Fig. 2 ). The 2 bp difference between alleles (116 bp and 118) was clearly demonstrated. This system gives the best separation in and under this molecular weight range. Microsatellites have a multiband appearance that is resolved by denaturing sequencing gels. ${ }^{(9)} \mathrm{We}$ have a similar phenomenon in our system; every allele has a main band and a trailing shadow band. The homozygote $116 / 116$ genotype has two additional faint bands at the 150 -bp region, that are not seen on the sequencing gel. These bands must be PCR artifacts, which do not complicate the genotypic interpretation.

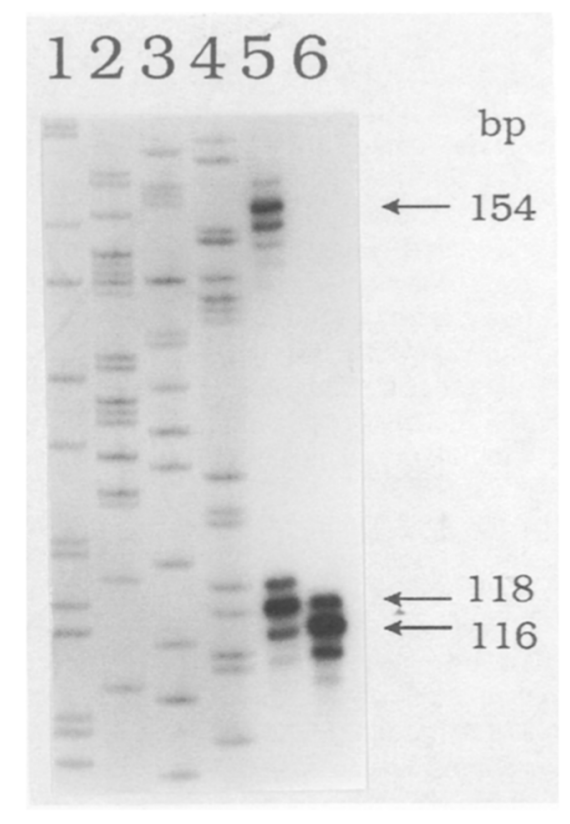

FIGURE 1 Separation of microsatellite alleles on a $6 \%$ denaturing polyacrylamide sequencing gel. (Lanes 1-4) DNA sequencing ladders prepared from a known sequence; (lane 5) genotype 118/154; (lane 6) genotype 116/116. 


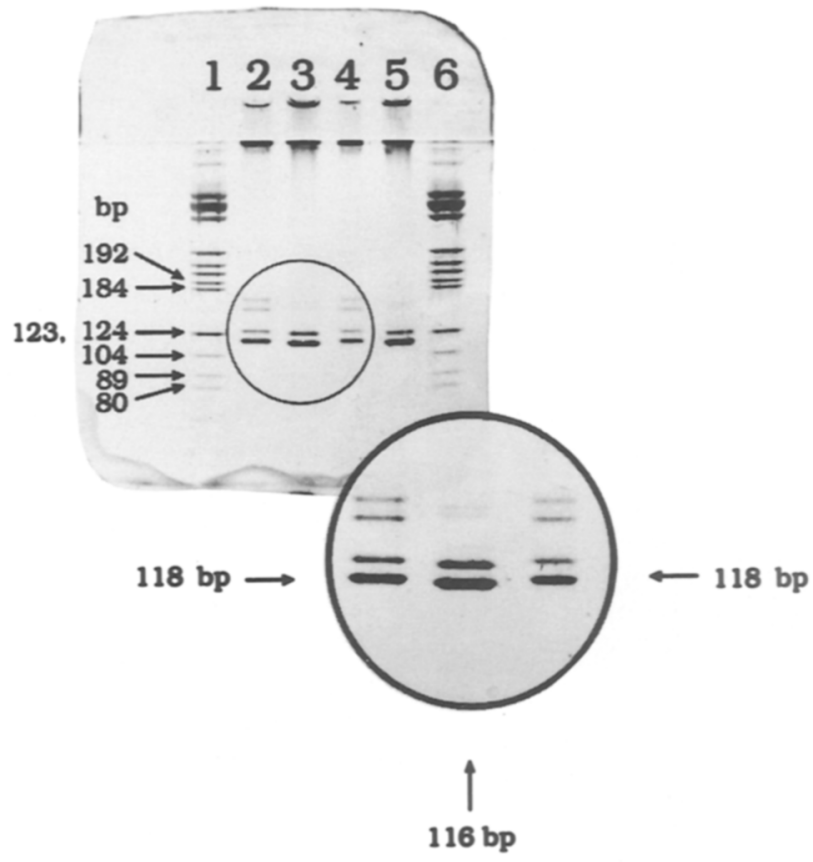

FIGURE 2 Separation of microsatellite alleles on $8 \%$ nondenaturing polyacrylamide gel by the PhastSystem. (Lanes 1,6) DNA molecular weight marker V (Boehringer); (lanes 2,4) genotype 118/154; (lanes 3,5) genotype 116/116.

Using this high-resolution technique, 20 min after finishing the PCR reaction the gels were developed, without the need of radioactive compounds and the time-consuming electrophoresis of sequencing gels.

\section{ACKNOWLEDGMENTS}

We are grateful to Drs. L. Orbán for his valuable suggestions, Professor L. Orosz for his support, and A. Chrambach and M. Garner (National Institutes of Health) for critical reading of the manuscript. We also thank Anikó Illés for her skilled technical assistance.

\section{REFERENCES}

1. Hamada, H., M. Petrino, and T. Kakunaga. 1982. A novel repeated element with Z-DNA-forming potential is widely found in evolutionarily diverse eukaryotic genomes. Proc. Natl Acad. Sci. 79: 64566459.

2. Weber, J.L. and P.E. May. 1989. Abundant class of human DNA polymorphisms which can be typed using the polymerase chain reaction. Am. J. Hum. Genet. 44: 388-396.

3. Litt, M. and J.A. Luty. 1989. A hypervariable microsatellite revealed by in vitro amplification of a dinucleotide repeat within the cardiac muscle actin gene. Am. J. Hum. Genet. 44: 397-401.

4. Tautz, D. 1989. Hypervariability of simple sequences as a general source for polymorphic DNA markers. Nucleic Acids Res. 17: 6463-6471.

5. Love, J.M., A.M. Knight, M.A. McAleer, and J.A. Todd. 1990. Towards construction of a high resolution map of the mouse genome using PCR-analysed microsatellites. Nucleic Acids Res. 18: 41234130.

6. Dietrich, W., H. Katz, S.E. Lincoln, H.S. Shin, J. Friedman, N.C. Dracopoli, and E.S. Lander. 1992. A genetic map of the mouse suitable for typing intraspecific crosses. Genetics 131: 423-447.

7. Wiltfang, J., N. Arold, and V. Neuhoff. 1991. A new multiphasic buffer system for sodium dodecyl sulfate-polyacrylamide gel electrophoresis for proteins and peptides with molecular masses 100,000 1,000 , and their detection with picomolar sensitivity. Electrophoresis 12: 352-366.

8. Zsolnai, A., L. Orbán, and A. Chrambach. 1993. Agarose electrophoresis of DNA in discontinuous buffers, using a horizontal slab apparatus and a buffer system with improved properties. Electrophoresis 14: 179-184.

9. Litt, M., X. Hauge, and V. Sharma. 1993. Shadow bands seen when typing polymorphic dinucleotid repeats: some causes and cures. BioTechniques 15: 280-284.

Received January 26, 1995; accepted in revised form March 29, 1995. 


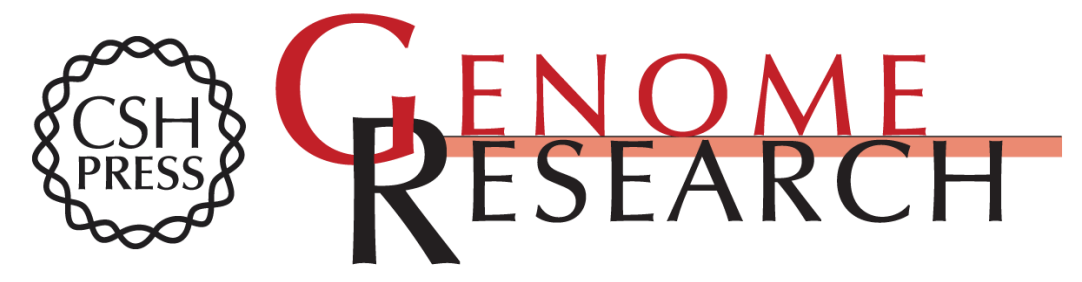

\section{Rapid method for separation of microsatellite alleles by the PhastSystem.}

Z Buzás and L Varga

Genome Res. 1995 4: 380-381

References This article cites 9 articles, 1 of which can be accessed free at: http://genome.cshlp.org/content/4/6/380.full.html\#ref-list-1

License

Email Alerting

Receive free email alerts when new articles cite this article - sign up in the box at the Service top right corner of the article or click here.

\section{Affordable, Accurate Sequencing.}

To subscribe to Genome Research go to: https://genome.cshlp.org/subscriptions 